\title{
Pengembangan Teknologi E-Marketplace Jasa Penjahit di KOTIM dengan Metode SMART dan Location Based Services
}

\author{
Cicilia Elfrida Atiaini, Mustaqiem, Minarni* \\ Fakultas Ilmu Komputer, Program Studi Sistem Informasi, Universitas Darwan Ali, Sampit, Indonesia \\ Email: 1'ciciliaelfrida19@gmail.com, ${ }^{2}$ qmost.4all@ gmail.com, ${ }^{3,{ }^{*}}$ minarnifikom2512@ gmail.com \\ Email Penulis Korespondensi: ciciliaelfrida19@gmail.com
}

\begin{abstract}
Abstrak-Perkembangan teknologi dengan begitu cepatnya dapat merubah sesuatu menjadi lebih mudah, cepat dan nyaman. Penggunaan teknologi itu sendiri tidak hanya menguntungkan satu pihak namun juga semua pihak, secara tidak langsung kita harus mengikuti perkembangan teknologi agar kita dapat lebih unggul dibandingkan yang lainnya. Dan dengan dunia maya yang tercipta karena berkembangnya teknologi internet itulah yang membuat secara tidak langsung membentuk sebuah pasar atau wadah perdagangan tersendiri yang biasa sekarang disebut sebagai e-marketplace. Sebagaimana pasar dalam pengertian konvensionalnya, yaitu tempat bertemunya penjual dan pembeli secara langsung, sedangkan pada e-marketplace sendiri para penjual dan pembeli bertemu di dunia maya dan tidak dibatasi oleh ruang maupun waktu. Penelitian ini dilakukan dengan menggunakan metode SMART dan Location Based Services. Teknik pengumpulan data dilakukan dengan cara observasi dan studi literatur. Dari hasil penelitian Pengembangan Teknologi E-Marketplace Jasa Penjahit di Kotim Dengan Metode SMART dan Location Based Services ialah emarketplace jasa penjahit ini untuk para penyedia layanan jasa penjahit memasarkan atau menjual jasanya di wilayah Kotim, program yang dibuat dapat digunakan untuk para pengguna jasa penjahit dalam mencari lokasi penjahit, dan program yang dibuat ini pula dapat digunakan untuk para pengguna jasa penjahit dalam menentukan penjahit mana yang akan dipilih berdasarkan beberapa penilaian dari kriteria penjahit yang ada.
\end{abstract}

Kata Kunci: E-marketplace; Jasa Penjahit; Location Based Services; SMART; Teknologi

Abstract-The rapid development of technology can make things easier, faster and more comfortable. The use of technology itself does not only benefit one party but also all parties, indirectly we must follow technological developments so that we can be superior to others. And with the virtual world created because of the development of internet technology, it is what indirectly creates a separate market or trading platform which is now commonly referred to as an e-marketplace. As the market in its conventional sense, which is a place where sellers and buyers meet directly, while in e-marketplaces, sellers and buyers meet in cyberspace and are not limited by space or time. This research was conducted using the SMART method and Location Based Services. Data collection techniques were carried out by means of observation and literature study. From the results of the research on the Development of E-Marketplace Technology for Tailor Services in Kotim with the SMART method and Location Based Services, this is an e-marketplace for tailor services for tailor service providers to market or sell their services in the Kotim area, the program created can be used for tailor service users. in finding a tailor's location, and the program created can also be used for tailor service users in determining which tailor to choose based on several assessments of the existing tailor criteria.

Keywords: E-marketplace; Tailor Service; Location Based Services; SMART; Technology

\section{PENDAHULUAN}

Seiring dengan perkembangan di bidang teknologi informasi pada saat sekarang ini, dimana akses internet bukan menjadi sesuatu yang mahal namun sudah menjadi kebutuhan. Para pengguna internet dimudahkan dengan mendapatkan informasi secara praktis kapanpun dan di manapun atau perusahaan-perusahaan banyak melakukan promosi melalui jaringan sosial, misalnya membuat promosi melalui teknologi sekarang dengan salah satunya digunakan yaitu website. Dengan adanya akses internet dapat mudah membuat bergesernya model konvesional beralih ke model serba digital dan elektronik. Seperti halnya pada pasar saat ini sudah mulai bergeser dengan munculnya $e$-marketplace atau disebut dengan pasar online (Sirait \& Seabtian, 2019).

Sistem e-marketplace dapat mempermudahkan pembeli dan penjual untuk melakukan transaksi secara mudah, praktis dan dapat menghemat waktu. Hanya melalui aplikasi website kemudian tinggal klik para pembeli dan penjual sudah dapat melakukan transaksi sehingga tidak perlu bertemu secara langsung. Hal tersebut tentunya saja membuat bergesernya cara konvensional dan beralih ke model online (Sirait \& Seabtian, 2019). E-marketplace memanfaatkan media digital seperti internet yang berguna untuk menciptakan suatu lingkungan atau tempat yang akan mewadahi para penjual dan pembeli untuk melakukan proses-proses bisnisnya mulai dari pemasaran produk, penawaran produk, mengembangkan komunikasi antara penjual dan pembeli sehingga terciptalah kepuasan terhadap keduanya (Setiyawan et al., 2015).

Pada saat ini banyak sekali terdapat situs website e-marketplace yang bermunculan misalnya saja seperti www.tokopedia.com, www.shopee.com dan berbagai e-marketplace lain. Situs website e-marketplace tersebut sangat menjamur karena menjadi tempat yang sangat cocok untuk para penjual dalam memasarkan barang dagangannya dan tentu saja juga mempermudah para calon pembeli dalam mencari informasi barang yang ingin dibeli maupun yang dibutuhkannya (Ryan, 2019).

Meskipun banyak $e$-marketplace yang telah ada, namun belum ada situs $e$-marketplace yang di khususkan untuk para (Ryan, 2019) penyedia layanan jasa penjahit di wilayah Kotawaringin Timur. Para penyedia layanan jasa penjahit di wilayah Kotawaringin Timur memasarkan atau menjual jasa mereka masih dengan cara konvesional. Banyak pengguna jasa jahit kesulitan mencari lokasi penjahit terlebih untuk penjahit rumahan yang tidak memasang spanduk atau papan 
nama pada tempat atau lokasi jahitnya. Dan tidak sedikit pula pengguna jasa jahit yang kesulitan dalam menentukan penjahit mana yang akan dipilih menyesuaikan dengan beberapa kriteria berikut seperti kualitas dari hasil pekerjaan penjahit, lama dari waktu pengerjaannya , layanan dari penjahit dan harga jasa jahit dari para penyedia jasa penjahit ini.

Diharapkan dengan dibuatnya e-marketplace jasa penjahit khusus wilayah Kotawaringin Timur ini dapat memberikan kemudahan serta memberikan sebuah wadah kepada para penyedia layanan jasa penjahit khususnya yang berada di wilayah Kotawaringin Timur untuk memasarkan jasanya, yaitu dengan menerapkan teknologi Location Based Services yang diharapkan juga dapat memberikan kemudahan kepada para pengguna jasa penjahit dalam mencari lokasi penjahit serta menggunakan metode SMART dalam pemberian rating pada penjahit untuk mempermudah para pengguna jasa penjahit menentukan penjahit mana yang akan dipilih berdasarkan beberapa penilaian kriteria penjahit.

\section{METODOLOGI PENELITIAN}

\subsection{Tahapan Penelitian}

Langkah-langkah yang dilakukan pada penelitian ini untuk mencapai tujuan ialah sebagai berikut ini:

a. Analisa, dilakukan dengan menganalisa e-marketplace pelayanan jasa lainnya yang serupa seperti www.starofservice.co.id, www.carijasa.co.id, www.beres.id, www.sejasa.com, www.ahlijasa.com, dan www.seekmi.com,

b. Studi literatur, dilakukan dengan cara mempelajari buku, sebuah file atau dokumen yang diperlukan dalam penelitian ini. Hal-hal yang diperlukan yaitu mengenai penggunaan metode pengambilan keputusan seperti SMART dan teknologi Location Based Services,

c. Perancangan dari model proses dan desain sistem,

d. Implementasi pembuatan sistem.

\subsection{Kajian Metode Penelitian}

\subsubsection{SMART (Simple Multi Attribute Rating Technique)}

Metode seperti Simple Multi Attribute Rating Technique ini merupakan salah satu metode dengan cara pengambilan keputusan multi kriteria yang dikemukakan dan dikembangkan sejak tahun 1971 oleh Edward (Harahap et al., 2021). Teknik pengambilan keputusan multi kriteria ini digunakan untuk mendukung pembuat keputusan dalam memilih beberapa alternatif (Damanik, 2021). Secara umum Metode Simple Multi Attribute Rating Technique (SMART) ialah merupakan suatu model pengambilan keputusan yang komperensif dengan memperhitungkan hal-hal bersifat kualitatif dan kuantitatif (Rahayu et al., 2021).

Metode SMART pada penelitian ini digunakan dalam perangkingan objek jasa penjahit berupa bintang penilaian dengan multi kriteria. Kriteria tersebut berupa kualitas dari hasil pekerjaan penjahit, lama dari waktu pengerjaannya, layanan dari penjahit dan harga jasa jahit dari para penyedia layanan jasa penjahit ini. Sehingga pengguna jasa jahit dapat melihat berapa bintang penilaian pada setiap masing-masing para penyedia layanan jasa penjahit, dan dapat memudahkan dalam memilih penjahit serta pengguna dapat pula memberikan bintang penilaian setelah melakukan transaksi.

\subsubsection{LBS (Location Based Services)}

Layanan Berbasis Lokasi atau lebih dikenal dengan Location Based Services (LBS) yang digunakan untuk menggambarkan teknologi untuk menemukan lokasi perangkat yang digunakan (Budiman, 2016). Location Based Services adalah aplikasi yang bergantung pada lokasi tertentu yang didefinisikan sebagai layanan informasi dengan memanfaatkan teknologi untuk mengetahui suatu posisi tertentu (Anwar et al., 2014). Layanan berbasis lokasi ini menggunakan teknologi Positioning System, teknologi ini memungkinkan para pengguna dapat memperoleh informasi mengenai suatu lokasi sesuai dengan kebutuhannya (Anwar et al., 2014).

Teknologi Location Based Services digunakan untuk suatu layanan yang bereaksi aktif pada perubahan posisi entitas yang mendeteksi letak objek. Pemberian layanan teknologi Location Based Services ini disesuaikan dengan posisi objek yang telah ditentukan dan pada penelitian ini ialah disesuaikan dengan posisi dan lokasi para penyedia layanan jasa penjahit ini dengan memanfaatkan longitude dan latitude. Sehingga mempermudah pengguna jasa jahit mencari lokasi para penyedia layanan jasa penjahit.

\section{HASIL DAN PEMBAHASAN}

Penganalisisan sistem ini bertujuan untuk mengetahui bagaimana sistem dapat diketahui kekurangan atau kelemahan pada sistem tersebut.

Tabel 1. Identifikasi Aktor

\begin{tabular}{cll}
\hline No. & Aktor & \multicolumn{1}{c}{ Deskripsi } \\
\hline 1. & Admin & Orang yang memiliki semua hak akses pada website e-marketplace Jasa Penjahit di \\
& Kotim & Orang yang menawarkan jasa pada website e-marketplace Jasa Penjahit di Kotim \\
\hline
\end{tabular}


TIN: Terapan Informatika Nusantara

Vol 2, No 8, Januari 2022, Hal 501-505

ISSN 2722-7987 (Media Online)

Website https://ejurnal.seminar-id.com/index.php/tin

DOI 10.47065/tin.v2i8.1149

\begin{tabular}{ccl}
\hline No. & Aktor & \multicolumn{1}{c}{ Deskripsi } \\
\hline 3. & Pelanggan & $\begin{array}{l}\text { Orang yang memesan jasa untuk membuat pakaian pada website e-marketplace Jasa } \\
\text { Penjahit di Kotim }\end{array}$ \\
\hline
\end{tabular}

Kemudian berikut ini adalah gambar Use Case Diagram dari sistem order jasa penjahit pakaian.

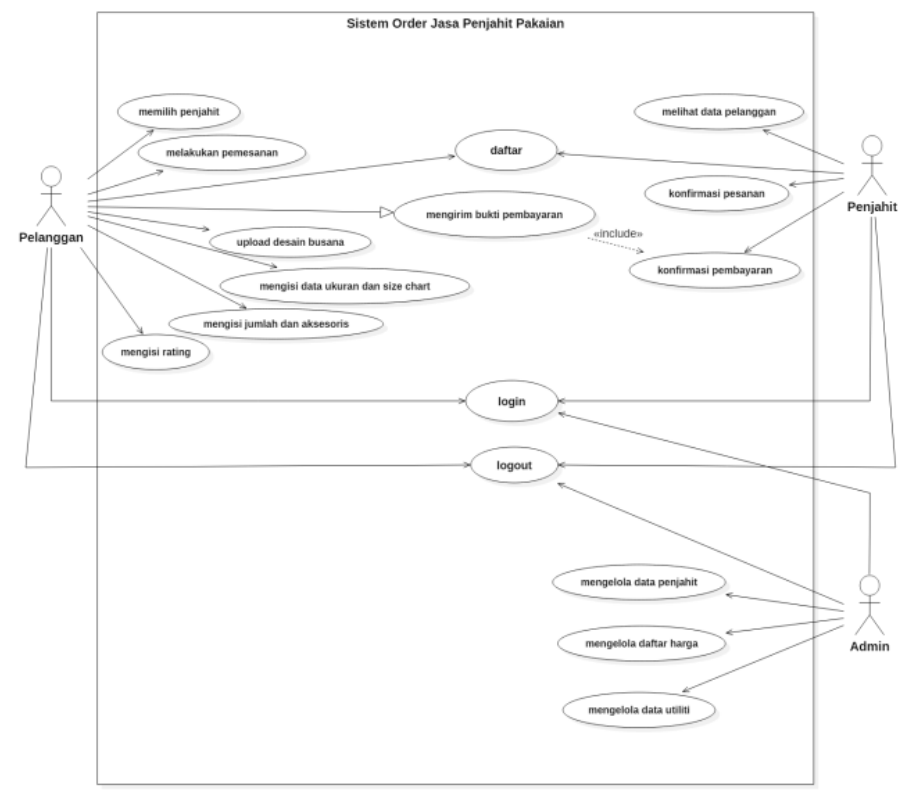

Gambar 1. Use Case Diagram Sistem Order Jasa Penjahit Pakaian

Use case diagram merupakan representasi dari interaksi antara aktor dengan sistem (Dharwiyanti \& Wahono, 2003). Sistem website ini digunakan untuk 3 aktor yaitu admin, penjahit dan pelanggan yang saling berinteraksi pada gambar 1. Admin dapat mengelola data penjahit, koleksi hasil jahitan para penjahit, data para pelanggan, serta daftar harga jahitan. Penjahit sendiri bisa menggunakan sistem website dengan registrasi terlebih dahulu, setelah melakukan registrasi penjahit dapat melihat data para pelanggannya, melakukan konfirmasi pesanan, dan konfirmasi pembayaran. Pelanggan bisa menggunakan sistem website dengan mendaftar terlebih dahulu, selanjutnya pelanggan dapat memilih penjahit yang ditampilkan pada peta, kemudian dapat memesan busana atau pakaian yang diinginkan. Pelanggan bisa memilih atau memberikan desain yang diinginkan, pelanggan dapat menginputkan data ukuran dan aksesoris yang diinginkan. Pelanggan melakukan pembayaran kepada penjahit berdasarkan nomor rekening dan mengirim bukti pembayaran, kemudian pelanggan melakukan penilaian atau memberikan rating untuk penjahit. Kemudian berikut ini adalah gambar class diagram dari sistem.

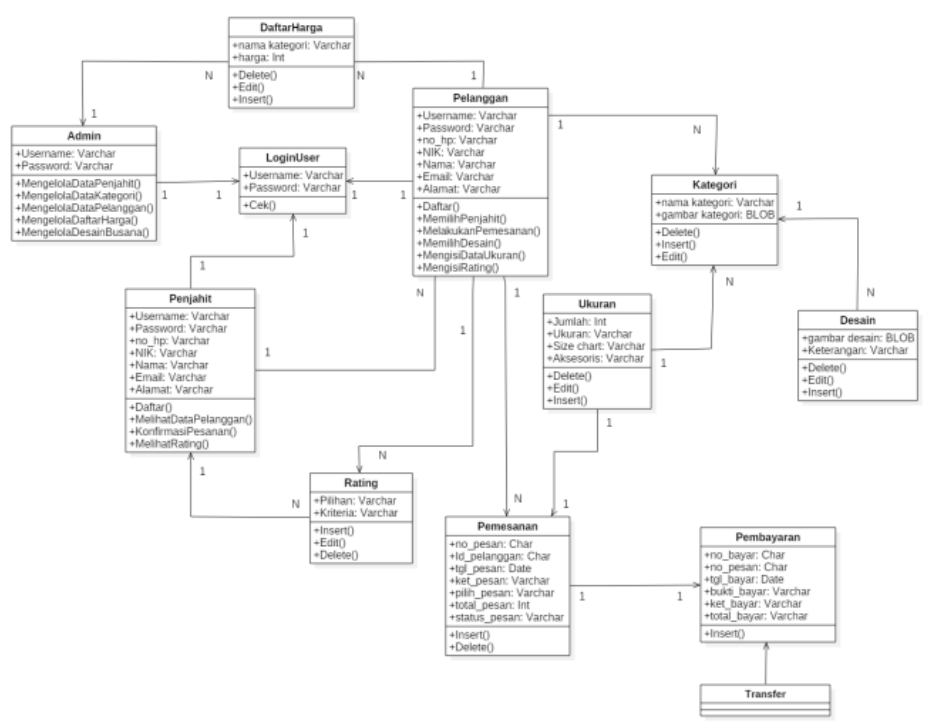

Gambar 2. Class Diagram

Pemodelan data digunakan untuk menampilkan relasi antar data-data yang digunakan dalam database dan class. Model data pada sistem ini digambarkan dalam bentuk class diagram yang terdiri dari sebelas class yang saling berelasi satu sama lain. Sebelas class diagram tersebut terdiri dari: a. diagram class admin dengan atribut yang terdiri dari (username dan password). Admin berwenang mengatur data penjahit, data pelanggan, data kategori, daftar harga serta 
mengatur data desain busana. b. Diagram class Login User dengan atribut (username dan password). c. Diagram class Penjahit dengan atribut (username, password, no_hp, NIK, nama, email, alamat). Penjahit dapat melakukan pendaftaran, melihat data para pelanggan, melakukan konfirmasi pesanan, dan melihat rating. d. Diagram class Pelanggan dengan atribut (username, password, no_hp, NIK, nama, email, alamat). Para pelanggan dapat melakukan pendaftaran, memilih penjahit yang diinginkan, melakukan pemesanan, memilih desain pakaian, mengisi data ukuran, dan mengisi rating. e. Diagram class Kategori dengan atribut (nama kategori dan gambar kategori). f. Diagram class Ukuran dengan atribut (kuantitas, ukuran, size chart, aksesoris). g. Diagram class Desain dengan atribut (gambar desain dan keterangan). h. Diagram class Daftar Harga dengan atribut (nama kategori dan harga). i. Diagram class Rating dengan atribut (pilihan dan kriteria). j. Diagram class Pemesanan dengan atribut (no_pesan, id_pelanggan, tgl_pesan, ket_pesan, pilih_pesan, total_pesan, dan status_pesan). k. Diagram class Pembayaran dengan atribut (no_bayar, no_pesan, tgl_bayar, bukti_bayar, ket_bayar, dan total_bayar).

\subsection{Implementasi}

Selanjutnya hasil implementasi sebuah program yang telah dibuat.

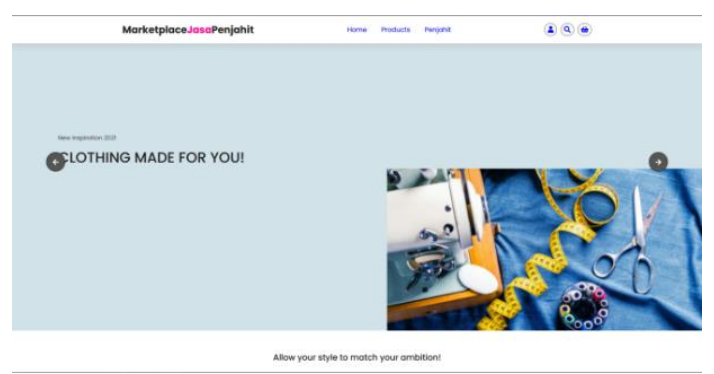

Gambar 3. Halaman Utama

Halaman utama pada website e-marketplace jasa penjahit ini untuk menampilkan tampilan gambar pakaian yang dapat dibuat oleh para penjahit. Selain itu juga terdapat pula beberapa menu yaitu menu produk, penjahit, login, daftar, beranda, dll. Gambar 3. diatas ini merupakan tampilan halaman utama dari website e-marketplace jasa penjahit. Dari halaman utama ini kita dapat melakukan pendaftaran atau login, kemudian dapat melihat produk pada menu produk dan melihat penjahit pada menu penjahit kemudian selanjutnya dapat melakukan proses transaksi.

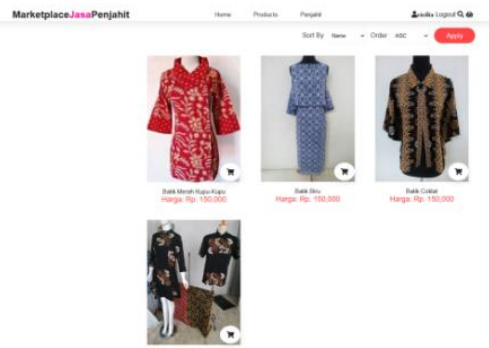

Gambar 4. Halaman Produk

Halaman produk pada website e-marketplace jasa penjahit ini untuk menampilkan semua produk dari para masingmasing penjahit. Sehingga para pelanggan dapat dimudahkan menentukan seperti apa model dari pakaian yang hendak dijahit oleh para penjahit. Gambar 4. diatas ini merupakan tampilan halaman produk dari website e-marketplace jasa penjahit.

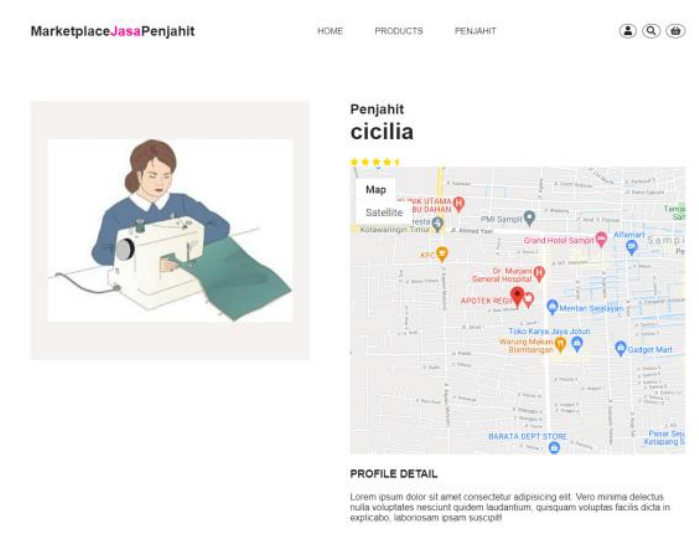

Gambar 5. Halaman Profil Penjahit dan Peta Lokasi 


\section{TIN: Terapan Informatika Nusantara}

Vol 2, No 8, Januari 2022, Hal 501-505

ISSN 2722-7987 (Media Online)

Website https://ejurnal.seminar-id.com/index.php/tin

DOI 10.47065/tin.v2i8.1149

Halaman profil penjahit dan peta lokasi pada website e-marketplace jasa penjahit ini untuk menampilkan profil para masing-masing penjahit yang terdapat pada website e-marketplace jasa penjahit ini, sekaligus pula akan ditampilkan peta lokasi dari masing-masing penjahit sesuai titk pada peta secara akurat. Gambar 5. diatas ini merupakan tampilan halaman profil penjahit dan peta lokasi pada website e-marketplace jasa penjahit.

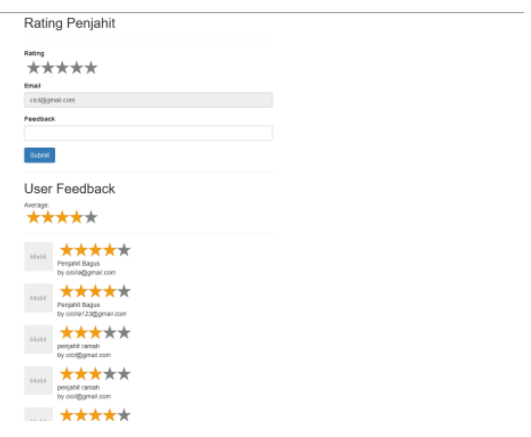

Gambar 6. Halaman Rating Penjahit

Halaman rating penjahit pada website e-marketplace jasa penjahit ini untuk menampilkan rating para penjahit, selain dapat menampilkan rating pada halaman rating penjahit ini para pelanggan juga dapat menginput ratingnya dengan memberikan bintang dan feedback pada masing-masing kriteria yang ada pada penjahit. Gambar 6. diatas ini merupakan tampilan halaman rating penjahit pada website e-marketplace jasa penjahit.

\section{KESIMPULAN}

E-marketplace jasa penjahit ini untuk para penyedia layanan jasa penjahit memasarkan atau menjual jasanya di wilayah KOTIM. Program yang dibuat dapat digunakan untuk para pengguna jasa penjahit dalam mencari lokasi penjahit dengan memanfaatkan Location Based Services. Dan dapat pula digunakan untuk para pengguna jasa penjahit dalam menentukan penjahit mana yang akan dipilih berdasarkan beberapa penilaian kriteria penjahit dengan memanfaatkan metode SMART.

\section{UCAPAN TERIMAKASIH}

Terima kasih disampaikan kepada pihak-pihak yang telah mendukung terlaksananya penelitian ini. Saya selaku penulis ingin mengucapkan terimakasih kepada peneliti terdahulu, dan terlebih untuk berbagai aspek yang bisa saya temukan mengenai penelitian karena banyaknya ilmu dan sumber pengetahuan diluar sana yang bisa saya jadikan sebegai referensi untuk penelitian ini.

\section{REFERENCES}

Anwar, B., Jaya, H., Kusuma, P. I., Studi, P., \& Komputer, S. (2014). Issn: 1978-6603 implementasi location based service berbasisandroid untuk mengetahuiposisi user. 121-133.

Budiman, E. (2016). Pemanfaatan Teknologi Location Based Service Dalam Pengembangan Aplikasi Profil Kampus Universitas Mulawarman Berbasis Mobile. ILKOM Jurnal Ilmiah, 8(3), 137-144. https://doi.org/10.33096/ilkom.v8i3.81.137-144

Damanik, R. (2021). Penentuan Minat Baca Siswa Dalam Peminjaman Buku Dengan Metode Smart (Simple Multi Attribut Rating Technique) Romanus Damanik 1). Jik), 5(2).

Dharwiyanti, S., \& Wahono, R. S. (2003). Pengantar Unified Modeling LAnguage (UML). IlmuKomputer.Com, 1-13. http://www.unej.ac.id/pdf/yanti-uml.pdf

Harahap, A. R., Iswan, M., \& Murniyanti, S. (2021). Sistem Pendukung Keputusan Reqruitment Kredit Perumahan Rakyat Bersubsidi Dengan Menggunakan Metode. Jurnal CyberTech, 1(1), 63-71.

Rahayu, N. A., Ginting, B. S., \& Simanjuntak, M. (2021). Sistem Pendukung Keputusan Seleksi Penerimaan Bantuan Program Sembako Menggunakan Metode Smart (Simple Multi Attribute Rating Technique) (Studi Kasus : Dinas Sosial Kota Binjai). Jurnal Sistem Informasi Kaputama (JSIK), 5(1), 63-74. https://jurnal.kaputama.ac.id/index.php/JSIK/article/view/468

Ryan, F. (2019). BAB I PENDAHULUAN 1.1 Latar Belakang Pada era. 1-8.

Setiyawan, A., Kodong, F. R., \& Kaswidjanti, W. (2015). Model Aplikasi E-Market Sebagai Sarana Promosi Dan Tukar Menukar Informasi Antara Penjual Dan Pembeli. Telematika, 8(2). https://doi.org/10.31315/telematika.v8i2.446

Sirait, D. A. E., \& Seabtian, D. T. (2019). Sistem Informasi E-Marketplace Cindramata Sampit Berbasis Web. Jurnal Penelitian Dosen FIKOM (UNDA), 10(1). http://jurnal.unda.ac.id/index.php/Jpdf/article/view/125 